ДОБРЫНИНА Мария Владимировна - кандидат политических наук, доцент кафедры экономики, менеджмента и финансов Национального исследовательского университета «Московский институт электронной техники» (124498, Россия, г. Москва, Зеленоград, пл. Шокина, 1)

НИКИТИНА Светлана Сергеевна - доктор политических наук, профессор кафедры организации деятельности органов внутренних дел Центра командно-итабных учений Академии управления МВД России (125171, Россия, г. Москва, ул. Зои и Александра Космодемьянских, 8)

\title{
РАЗВИТИЕ ИНЖЕНЕРНОГО ОБРАЗОВАНИЯ В РОССИИ В ПОСТПЕТРОВСКИЙ ПЕРИОД XVIII В.: ОСНОВНЫЕ ТЕНДЕНЦИИ И ПРОТИВОРЕЧИЯ
}

Аннотация. В статье автор констатирует противоречивость и непоследовательность изменений, имевших место в инженерном образовании в середине XVIII в. Качество инженерного образования выросло, однако оно утратило свое стратегическое для страны значение. Главной тенденцией, характеризующей развитие инженерного образования в последнее десятилетие XVIII в., было возвращение к принципам всесословности и практикоориентированности.

Ключевые слова: образовательная система, инженерное образование, государственная политика, принципы образования, инновационный шок

Э поха Петра I справедливо считается периодом становления российской системы инженерно-технического образования. Реформы Петра I - решение инновационного конфликта через форсированную модернизацию всех сфер жизни государства и общества в режиме «сверху» - включали систему мер по развитию инженерного дела, фундации системы инженерного образования (импорт иностранных специалистов, открытие инженерных школ и инженерных рот, стимулирование развития частных школ, мотивирование дворянских детей и третьего сословия к получению инженерного образования) и оформлению наиболее значимых принципов осуществления государственной политики в отношении инженерного образования. К их числу относятся: 1) ориентация в подготовке специалистов на военно-стратегические задачи государства; 2) отказ от элитарности, расширение доступа к образованию, государственной военной и гражданской службе для различных сословий; 3) расширение образовательного пространства, максимизация числа «точек доступа к обучению»; 4) принцип импорта знаний и специалистов, интернационализация образования; 5) практикоориентированность и адаптивность по отношению к военным и экономическим нуждам государства.

Во второй четверти XVIII в. структура кадровой потребности в инженерах по отношению к Петровскому времени качественно не изменилась, в количественном отношении запрос экономики на квалифицированных технических специалистов даже вырос. Войны 1730-1740-х гг., а также градостроительные потребности выказывали острую нехватку «людей, просвещенных наукам и искусных в ремеслах» [Лалаев 1880: 32]. Однако после смерти Петра I многие начинания и инициативы в области образовательной и научной политики не получили своего продолжения; развитие инженерного дела перестало быть стратегически важной задачей государства, и в целом политика в отношении инженерного образования во второй четверти XVIII в. носила противоречивый характер.

Часть учебных заведений инженерного профиля были объединены (столич- 
ная инженерная и артиллерийская школы), а контингент слушателей инженерных школ Киева, Москвы и Санкт-Петербурга то увеличивался (до 1743 г.), то уменьшался (в 1745 г. число слушателей Санкт-Петербургской школы снова было сокращено) [Ласковский 1858-1865: 656-657]. Если при Петре I качество инженерного образования рассматривалось как дело государственной важности, а профессорско-преподавательский состав, учебные планы и программы, учебные пособия были предметом личного попечения монарха, то в 17301740-х гг. государственный контроль за качеством обучения был ослаблен. Эти изменения привели к тому, что в 1750-х гг. число обучающихся в инженерных учебных заведениях примерно равнялось показателям 1730 г., а качество специальной подготовки технических специалистов снизилось по сравнению с позднепетровским временем [Савельев 1879: 91].

Потребность в технических специалистах во всех сферах продолжала компенсироваться за счет привлечения иностранцев, причем часто именно иностранцам поручалось руководство и исполнение проектов, требовавших наиболее высокой квалификации. Обнаружился и дисбаланс между военной и гражданской сферами. Ввиду того что в первые десятилетия XVIII в. инженерное образование было нацелено преимущественно на удовлетворение военных нужд государства, а инженерные школы ограничивали свои цели тем, чтобы «приготовлять для артиллерии и инженерного ведомства знающих свое дело унтерофицеров и кондукторов, которые могли бы толково и сознательно выполнить приказания главных распорядителей и под их руководством приобретать по службе новые знания, необходимые для дальнейшего повышения» [Савельев 1879: 28], квалификация специалистов, окончивших инженерные школы и широко привлекавшихся к гражданским проектам (строительство городов, дворцов, дорог, гидротехнических сооружений) оказывалась совершенно недостаточной. Таким образом, в инженерном образовании наметился системный кризис, который усиливался ввиду децентрализации управления этой сферой: первые инженерные школы находились в ведении Приказа военных дел (до 1711 г.), Военной канцелярии (до 1720 г.); Военной коллегии; генерала-фельдцейхмейстера, обер-директора над фортификациями всей империи. Период дворцовых переворотов завершил системный кризис: инженерное образование, наука, просвещение не интересовали группы влияния, боровшиеся за власть в России.

Во второй половине XVIII в. на политику государства в отношении инженерного образования воздействовали новые политические, экономические и социокультурные факторы по сравнению с теми, которые детерминировали его развитие в эпоху Петровских реформ. В этот период «общество предъявило образовательной системе новые требования: подготовки специалистов в области науки, промышленности и транспорта. В результате в аксиологическую парадигму образования вошли профессионализм и полезность, став, с одной стороны, отражением ценностной парадигмы Просвещения, с другой - естественным следствием объективных процессов, происходящих в обществе. С Петровской эпохой часто сравнивают современный этап развития постсоветских государств, а Петровские реформы, напротив, иногда полагают первым этапом глобализации и интеграции России в единое общемировое пространство экономики, политики, науки и культуры. В наше время, как и в Петровскую эпоху, пересматриваются требования к понятию “профессионализм”, который и тогда, и сегодня в качестве системообразующего компонента включает в себя знание нескольких иностранных языков» [Растимешина, Лункина 2015: 97].

Реформы привели к тому, что Россия к середине XVIII в. была уже необратимо интегрирована в европейское образовательное пространство. В результате 
реформ и секуляризации административной сферы в России интенсивно развивалось светское образование. В соответствии с замыслом Петра, считавшего, что прорыв России во всех сферах жизни может быть обеспечен за счет синтеза науки и образования, были открыты Академия наук и университет ${ }^{1}$. Важность учреждения в России первого университета и первого центра развития фундаментальной науки невозможно переоценить и сегодня. Это событие качественно изменило не только сферу образования и науки, но и общественное мировоззрение в целом, поскольку «широта охвата в университетском познании явлений объективной и научной реальности позволяет говорить о том, что с этого времени изменился подход к образовательному процессу и самой категории знания» [Пирогов, Растимешина 2015: 76]. Изменения происходили относительно медленно: показательно в этом отношении, что многие просвещенные аристократы полагали, что «Академия оная с великим расходом будет бесполезна» [Татищев 1979: 105], что фундаментальная наука и всесословное высшее образование являются для России ненужной и несвоевременной роскошью. Однако развитие национальной науки стало приоритетом образовательной политики, несмотря на все внутренние противоречия, в т.ч. самой политики.

В России благодаря деятельности М.В. Ломоносова появились первые учебные программы и учебные планы, разработанные для учебных заведений разных профилей и ставшие фактически универсальными для образовательных учреждений соответствующих профилей и уровней, в т.ч. для инженерных школ [Лалаев 1880: 144]. Ломоносов как никто другой своей кипучей педагогической, исследовательской и научной деятельностью способствовал интериоризации русским сознанием ценностей Просвещения. Именно благодаря учебным программам, разработанным Ломоносовым, в инженерное образование были индоктринированы принципы научности, а преподавание начало ориентироваться на фундаментальность, энциклопедизм и универсализм (не в ущерб необходимой практикоориентированности). Сам академик М.В. Ломоносов читал лекции по физике, химии, физической химии, которые могли посещать студенты не только академического университета, но и инженерных школ.

Продолжателем дела М.В. Ломоносова был И.И. Шувалов, который с 1756 г. исполнял должность фельдцейхмейстера и главноначальствующего над Инженерным корпусом. Под влиянием М.В. Ломоносова и по инициативе И.И. Шувалова в учебные планы инженерных школ были введены гуманитарные и естественные науки: география, история, немецкий и французский языки. В 1758 г. в докладе на высочайшее имя И.И. Шувалов предложил императрице реорганизовать инженерное образование, подведя под него фундаментальную научную базу, констатировав неутешительное состояние образования во вверенных ему учреждениях и сделав особый акцент на кадровой проблеме: «Между тем, хотя школы в обоих сих корпусах есть, токмо они, от неимения знающих учителей и от весьма ограниченного своего учреждения, так недостаточны, что, чисто сказать можно, надежда не есть желания достигнуть; следственно, на оном основании людей, посвященных науками и искусных в ремеслах, получить нельзя» ${ }^{2}$. Кроме того, в своем докладе И.И. Шувалов впервые в истории российского образования ставит проблему неотделимости воспитания и обучения. Несмотря на то что проект реорганизации, предложенный И.И. Шуваловым, был одобрен, он так и не был воплощен в практической дея-

\footnotetext{
1 Полное собрание законов Российской империи. 1-е изд. (ПСЗРИ-1). Т. VII. СПб. 1830. № 4807. С. $553-$ 554.

2 Архив Военно-исторического музея артиллерии, инженерных войск и войск связи (Архив ВИМАиВС). Ф. 52. Оп. 113. Д. 12. Л. 5.
} 
тельности: историки предполагают, что на осуществление проекта не нашлось бюджетных средств, поскольку Россия вела разорительную Семилетнюю войну. Тем не менее И.И. Шувалов и его последователи в течение нескольких десятилетий проводили реорганизацию инженерного образования в корпусах, приведшую к повышению уровня профессиональной подготовки.

Одной из основных тенденций, определявшей государственную образовательную политику периодов правления Елизаветы II, Петра III и Екатерины II, была ориентация на классово-сословный принцип образования. Главным объектом государственных усилий стали в первую очередь дворянские (шляхетские) дети. В 1731 г. в Петербурге был учрежден первый российский кадетский корпус. Как и при Петре I, дворяне не спешили отдавать сыновей на обучение, в связи с чем высочайшие повеления кодифицировались в указах «Об определении детей дворянских в кадетский корпус» и «О записи дворян в кадетский корпус». В 1752 г. указом Елизаветы II были упразднены адмиралтейская и гардемаринская школы и был создан морской шляхетский корпус по аналогии с кадетским. Преемник графа Шувалова А.Н. Вильбоа инициировал создание артиллерийского и инженерного шляхетского кадетского корпуса в Петербурге. По своей сути кадетский и морской корпуса стали закрытыми элитными престижными учебными заведениями с серьезным уровнем подготовки по фундаментальным наукам, осуществлявшими общую и специальную профессиональную подготовку дворян к государственной военной и гражданской службе. Особое внимание при подготовке специалистов в них уделялось естественным и гуманитарным наукам: идеи фундаментальности и наукосообразности реализовывались в учебных планах в полной мере. Особое внимание в школах уделялось воспитанию будущего цвета российского дворянства, поэтому кадетские школы были особым предметом гордости императрицы. Она писала: «Во Франции думают, что мои кадеты приготавливаются единственно для войны; может быть, Парижская военная школа ввела [так думающих] в это заблуждение. Мои кадеты сделаются всем тем, чем пожелают быть, и выберут себе поприще по своим вкусам и наклонностям» [Лушников 1998].

Вместе с тем, несмотря на позитивные социокультурные изменения, в середине XVIII в. инженерное образование продолжало оставаться на периферии государственных забот и попечения. При росте качества инженерных знаний, обеспеченного серьезным преобразованием всей организации обучения и воспитания в инженерной и артиллерийской школах, кадетских корпусах, численность слушателей сокращалась, в первую очередь из-за уменьшения социального и политического запроса на инженерных специалистов. Инженерное образование в этот период утратило для страны свое стратегическое значение. Выпускникам школ не поручались масштабные задачи, которые их предшественникам приходилось решать в период Петровских реформ. В $1750-1760-$ х гг. инженерное ведомство решало преимущественно хозяйственные проблемы (заготовление, учет и хранение материалов, казенное строительство и т.п.). Среди выпускников кадетских школ есть выдающиеся полководцы и ученые, но относительно мало людей, прославившихся на инженерном поприще.

На фоне общего застоя в инженерном образовании определенное исключение составляет развитие горно-инженерного дела, начавшееся на Урале в середине века. Бурно развивавшаяся отрасль ощущала острую нехватку квалифицированных специалистов. Согласно докладу Берг-коллегии, проекту училища и плану обучения, утвержденным Екатериной II 21 октября 1773 г., при Берг-коллегии в Петербурге было учреждено первое в нашей стране горное училище ${ }^{1}$, которое,

\footnotetext{
${ }^{1}$ ПСЗРИ-1. ХІХ. СПб. 1830. № 14048. С. 841.
} 
по мнению некоторых специалистов, следует считать первым инженерным высшим учебным заведением в России. Открытие училища было приурочено ко дню восшествия императрицы на престол, и до конца царствования Екатерины II вуз находился под высочайшим попечением. Горное училище было первым узкоспециализированным учебным заведением, которое было учреждено для подготовки профессиональных кадров для одной, но имевшей стратегическое значение отрасли национального хозяйства ${ }^{1}$. Петербургское горное училище стало первым в своем роде исследовательским университетом, где наряду с преподаванием велась активная научно-исследовательская деятельность. Немаловажно также, что с открытием горного училища начала активно развиваться традиция попечительства над учебными заведениями. Горнопромышленники Урала ежегодно перечисляли на содержание училища сумму, фактически равную ежегодным тратам государственного бюджета. Благодаря такому частно-государственному партнерству учебное заведение не испытывало трудностей в содержании и развитии материально-технической, лабораторной, учебной базы, содержании профессорско-преподавательского состава, а также содержании и обучении казенных студентов [Научно-исторический... 1873; Татищев 1979: 201; Лалаев 1880]. Лучшие выпускники училища за казенный счет отправлялись для продолжения обучения в Западную Европу. Горное училище - одно из немногих учебных заведений России XVIII в., которое развивалось поступательно: благодаря достаточному финансированию, вниманию со стороны императрицы, выдающемуся составу высококвалифицированных преподавателей, качественной материальной базе училище поставляло отрасли качественных инженеров горного дела.

Период короткого, но яркого царствования Павла I стал особенным в истории российского инженерного образования. При всей противоречивости его личности и многих направлений проводимой им политики политика в отношении образования была последовательной и поступательной и была нацелена на расширение сети учебных заведений всех уровней: были открыты штурманские училища в Николаеве и Кронштадте, училища корабельной архитектуры в Петербурге и Николаеве, морское артиллерийское училище, а также большое число новых гарнизонных школ для детей солдат и матросов; число обучающихся в них выросло более чем в 5 раз. Флюгер, указывающий направление развития инженерного, особенно военно-инженерного, образования, снова развернулся от сословности, элитарности и фундаментальности к всесословности и практикоориентированности [Успенский 1994: 110].

Качество образования в элитных кадетских корпусах было подвергнуто ревизии, которая обнаружила низкий уровень технических и специальных знаний у слушателей. Стремление к универсализму Екатерининской эпохи привело к тому, что специальные дисциплины инженерного профиля преподавались в меньшем объеме, чем фундаментальные науки и гуманитарные дисциплины. Согласно стратегии реформ Павла I (превращение России в регулярное государство) педагогический подход «от воспитания к обучению» в элитных учебных заведениях трансформировался в знаниеориентированный, а учебные планы кадетских корпусов были соответствующим образом изменены.

Однако реформы Павла I не получили своего продолжения, и в период роста капиталистической экономики и начала промышленной революции все еще актуальной для России проблемой оставался инновационный конфликт между кустарным производством и промышленной технологией.

${ }^{1}$ Русский биографический словарь. В 25 т. Т. 6. Дабелов-Дядьковский. СПб: Тип. И.Н. Скороходова. 1905. C. 231-232. 
Институционализация инженерной профессии, особенно в гражданской сфере, не была завершена, а отрасли национального хозяйства и военное дело не были в полной мере обеспечены отечественными техническими специалистами.

\section{Список литературы}

Лалаев М.С. 1880. Исторический очерк военно-учебных заведений, подведомственных Главному их управлению. От основания в России первых военных школ до исхода первого двадиатипятилетия благополучного иарствования государя императора Александра Николаевича 1700-1890. СПб. 542 с.

Ласковский Ф.Ф. 1858-1865. Материалы для истории инженернаго искусства в России. - Сочинения Ф. Ласковскаго, военнаго инженер-генерал-майора. СПб: Тип. Императорской акад. наук. Ч. ІІІ. С. 656-677.

Лушников А. М. 1998. Военно-учебные заведения России в 1861-1941 г2.: Социально-политические аспекты развития: дис. ... Д.и.н. Ярославль. 485 с.

Научно-исторический сборник, изданный Горным институтом ко дню его столетнего юбилея. 1873. СПб: Типография Императорской Академии наук. 542 с.

Пирогов А.И., Растимешина Т.В. 2015. Интернационализация образования в контексте формирования единого общеевропейского образовательного пространства. - Экономические и социально-гуманитарные исследования. № 1(5). C. 76-84.

Растимешина Т.В., Лункина Ю.В. 2015. Традиции в отечественном образовании: взгляд из нового тысячелетия. - Экономические и социально-гуманитарные исследования. № 1(5). С. 91-98.

Савельев А. И. 1879. Исторический очерк Инженернаго управления в России (сост. Ал. Савельев). СПб: Тип. Р. Голике. Ч. 1. VI. 322 с.

Татищев В.Н. 1979. Избранные произведения (под общ. ред. С.Н. Валка). Л.: Наука. 464 с.

Успенский Д. 1994. Россия в царствование Павла І. - Три века. Россия от Смуты до нашего времени. В 6 т. М.: Изд-во ГИСТ. 5. С. 103-113.

DOBRYNINA Maria Vladimirovna, Cand.Sci. (Pol.Sci.), Associate Professor of the Chair of Economics, Management and Finance, National Research University «Moscow Institute of Electronic Technology» (1 Shokina Sq, Zelenograd, Moscow, Russia, 124498)

NIKITINA Svetlana Sergeevna, Dr.Sci. (Pol.Sci.), Professor of the Chair of Organizing the Activities of the Internal Affairs Agencies, Center for Command and Staff Exercises, Academy of Management of the Interior Ministry of Russia (8 Zoe and Alexandra Kosmodemyanskih St, Moscow, Russia, 125171)

\section{THE DEVELOPMENT OF ENGINEERING EDUCATION IN RUSSIA IN THE POST-PETRINE PERIOD OF THE $18^{\text {TH }}$ CENTURY: MAIN TRENDS AND CONTRADICTIONS}

Abstract. The article analyzes the incoherence and inconsistency of the changes that took place in engineering education in the middle of the $18^{\text {th }}$ century. The quality of engineering education increased, but it lost its strategic importance for the country. The main trend that characterizes the development of engineering education in the last decade of the $18^{\text {th }}$ century was a return to the principles of participation of all estates and practical orientation.

Keywords: educational system, engineering education, state policy, principles of education, innovation shock 